\title{
Effect of hydrogen peroxide application on color and surface roughness of two restorative materials
}

\author{
Dilcele Silva Moreira Dziedzic, DDS, MSc'; Lucia Helena Ramos da Silva²; Bruna Luiza do Nascimento, DDS; \\ Marina Samara Baechtold, DDS, MSc'; Gisele Maria Correr, DDS, MSc, PhD5; Carla Castiglia Gonzaga, DDS, PhD ${ }^{5}$ \\ 'Professor, School of Dentistry, Universidade Positivo- UP, Curitiba, PR, Brazil \\ 2Undergraduate Student, School of Dentistry, Universidade Positivo- UP, Curitiba, PR, Brazil \\ ${ }^{3} \mathrm{MS}$ student, Graduate Program in Dentistry, Universidade Positivo- UP, Curitiba, PR, Brazil \\ ${ }^{4} \mathrm{PhD}$ student, Graduate Program in Dentistry, Positivo- UP, Curitiba, PR, Brazi \\ ${ }^{5}$ Professor, Graduate Program in Dentistry, Positivo -UP, Curitiba, PR, Brazil \\ ${ }^{5}$ Professor, Graduate Program in Dentistry, Positivo- UP, Curitiba, PR, Brazil
}

\begin{abstract}
Aim: This study investigated the effect of an in-office bleaching technique on lightness, color and surface roughness of two commercially available materials: a resin-modified glass-ionomer cement and a nanohybrid resin composite. Methods: Twelve disk-shaped specimens were prepared with both materials. The samples were bleached with $35 \%$ hydrogen peroxide. Bleaching was tested initially onto a smooth surface and later onto a polished one of the same specimens. The effect of the treatments on lightness and color was verified with a spectrophotometer. Surface roughness was measured with a digital surface roughness tester. The data were statistically analyzed by repeated measures ANOVA and post hoc Tukey's test (alpha $=0.05)$. Results: Significant variation in lightness and color was observed on the resin-modified glass-ionomer cement after the first bleaching procedure. Roughness increased significantly only after polishing the resin-modified glass-ionomer cement surface. Composite color variation was evident in the last observation period, but roughness and lightness variation due to bleaching and polishing was not significant. Conclusion: The bleaching treatment caused significant color alterations on the materials tested. This study observed that the application of in-office bleaching onto the glass-ionomer cement promoted clinically observable color alteration, and polishing after bleaching is contraindicated for this material.
\end{abstract}

Key words: Resin-modified glass-ionomer cement. Composite. In vitro bleaching. Color behaviour. Surface roughness.

Received for publication: January 22, 2017 Accepted: June 12, 2017

Corresponding author: Dilcele Silva Moreira Dziedzic Rua Prof. Pedro Viriato Parigot de Souza, 5300; $81280-330$

Curitiba, Paraná, Brazil Phone: $+55413317-3180$

Fax: $+55413317-3082$ Email: dilceledz@gmail.com

\section{Introduction}

Due to increased demand for aesthetic treatments, tooth bleaching has become a very popular procedure. Dental bleaching is considered an effective treatment, and various concentrations of carbamide peroxide $(\mathrm{CP})$ or hydrogen peroxide (HP) are used during at-home and in-office techniques. The immediate result of dental bleaching is directly related to the agent's concentration and exposure time, despite the result after completion of the treatment being similar, clinically ${ }^{1}$ and in vitro $^{2}$.

Patients should be advised that after the conclusion of the bleaching treatment restorations might require replacement, especially in anterior teeth, for not matching 
the tooth color achieved after the treatment. The restorations may darken more or less than the teeth after exposure to components in the oral environment, and may not respond to the same degree to the bleaching treatment. It is also recommended to carefully examine the restorations before a bleaching treatment and replace the ones without adequate sealing, in order to reduce the risks of adverse effects ${ }^{3}$. Restoration before the bleaching treatment is indicated to prevent sensitivity in non-carious cervical lesions and restoration replacement is recommended for those with marginal leakages. The effect of bleaching agents on restorative materials and adhesive/tooth interface has been investigated ${ }^{4}$, but has not been fully resolved because of the diverse material composition and experimental setting.

Composite resins and resin-modified glass-ionomer cements present organic resin matrix and inorganic filler particles. The bleaching agents can react differently with each phase or their interface. Bleaching treatments of restorative materials may affect surface gloss 5 , microhardness ${ }^{6,8}$, roughness ${ }^{6,7,9-12}$, color $^{13-16}$, and the amount of elutable components ${ }^{17,18}$. Surface polishing after bleaching may not restore the physical properties of the restorative material because subsurface layers up to $2.0 \mathrm{~mm}$ can be affected ${ }^{8}$. The interaction between the bleaching products with restorative materials is of clinical significance, and therefore needs to be evaluated. According to Wang et al. (2011), it is important to investigate the alteration of restorative materials to bleaching in order to minimize the need for replacement of restorations after this treatment ${ }^{9}$

The aim of this in vitro study was to investigate the effect of an in-office bleaching material onto two tooth-colored restorative materials, analyzing roughness, lightness and intrinsic color change. The null hypothesis of this study was that $35 \%$ HP would not result in significant roughness and color differences in the materials tested.

\section{Material and methods}

Disk-shaped specimens of a nanohybrid composite (Filtek Z250 XT, shade A3, Table 1) and of a resin-modified glassionomer cement (Vitremer, shade A3, Table 1) were prepared according to manufacturer's instructions $(\mathrm{n}=12)$. Each specimen (1.0 $\mathrm{mm}$ thick and $10.0 \mathrm{~mm}$ in diameter) was prepared after inserting the restorative material into a cylindrical nylon matrix and pressing between two polyester strips and two glass slides. The material was initially light-cured through the polyester strip; to ensure thickness uniformity. Specimens were polymerized by a LED unit (Optilight Max, DabiAtlante, Brazil) for 40 seconds $\left(1000 \mathrm{~mW} / \mathrm{cm}^{2}\right)$. The protective gloss included in the Vitremer kit was applied and polymerized onto both sides of Vitremer disks.

Table 1 - Chemical composition and manufacturer of materials used in the present study.

\begin{tabular}{|c|c|c|c|c|}
\hline Material & Composition * & & Manufacturer & Batch Number \\
\hline Filtek Z250 XT & BIS-GMA, UDMA, BIS-EMA, PEGDMA, TEGDMA & $\begin{array}{l}\text { Zircônia/ silica particles } \leq 3 \text { microns, silica } \\
\text { particles } 20 \text { nanometer }\end{array}$ & $\begin{array}{l}\text { 3M ESPE, Dental Products, St. } \\
\text { Paul, MN, USA }\end{array}$ & 1501300548 \\
\hline Vitremer & $\begin{array}{l}\text { Powder: fluoroaluminosilicate glass, Potassium } \\
\text { persulfate } \\
\text { Gloss: TEGDMA, BIS-GMA }\end{array}$ & $\begin{array}{l}\text { Liquid: modified polycarboxylic acids } \\
\text { (methacrylate groups), water, HEMA }\end{array}$ & $\begin{array}{l}\text { 3M ESPE, Dental Products, St. } \\
\text { Paul, MN, USA }\end{array}$ & 1421100285 \\
\hline Whiteness HP Maxx & $\begin{array}{l}\text { 35\% Hydrogen Peroxide, thickener, dye, propylene } \\
\text { glycol, filler, water }\end{array}$ & & $\begin{array}{l}\text { FGM Produtos } \\
\text { Odontológicos, Joinville, SC, } \\
\text { Brazil }\end{array}$ & 131014 \\
\hline
\end{tabular}

*Information provided by manufacturers.

Abbreviations: Bis-GMA, Bisphenol-A-glycidyl methacrylate; Bis-EMA, Ethoxylated bisphenol-A-glycidyl methacrylate; HEMA, 2-Hydroxyethyl Methacrylate, PEGDMA, polyethylene glycol dimethacrylate; TEGDMA, Triethylene glycol dimethacrylate; UDMA, Urethane dimethacrylate.

The nonirradiated surfaces were identified and the specimens were stored in distilled water at $37^{\circ} \mathrm{C}$, with a weekly change of water. Two weeks after preparation, the specimens received the first bleaching treatment with Whiteness HP Maxx (35\% HP, Table 1). The bleaching protocol used onto the specimen's irradiated surfaces followed the manufacturer recommendation: three consecutive applications of the gel for 15 minutes each, after freshly mixing the bleaching component with the thickener, without light acceleration. After each bleaching application the specimens were wiped with gauze. The disks were rinsed with water for 1 minute after finishing the bleaching procedure, and stored in distilled water at $37^{\circ} \mathrm{C}$.

Two weeks after the first bleaching procedure the specimens were polished manually with 600 grit silicon carbide paper and water irrigation, and then thoroughly rinsed with tap water to remove any debris. Two weeks after polishing, the specimens received the second bleaching treatment. Bleaching was performed initially onto a smooth surface and later onto a polished one, of each specimen. The roughness of the disks was verified with a digital handheld surface roughness tester (Surftest SJ210P, Mitutoyo, Japan). The roughness value was calculated by averaging three readings of $\mathrm{Ra}$ (average roughness, measured in $\mu \mathrm{m})$ of each specimen from three different orientations.

CIELab color parameters of the specimens were measured with a spectrophotometer (VITA Easyshade Advance 4.0, VITA Zanfabrik, Germany) calibrated with a white reflectance standard tile supplied by manufacturer and the specimens were placed against a white background. Color variation $(\Delta \mathrm{E})$ was calculated using the following equation $(1)^{19}$.

$$
\Delta \mathrm{E}=\left[(\Delta \mathrm{L})^{2}+(\Delta \mathrm{a})^{2}+(\Delta \mathrm{b})^{2}\right]^{1 / 2}
$$


Where, the $\mathrm{L}^{*}$ represents the degree of lightness (ranges from 0 black, to 100 white), the $a^{*}$ coordinate represents the degree of green/red color $\left(-a^{*}\right.$ green, + a red), and the $b^{*}$ coordinate represents the degree of blue/yellow (-b* blue, $+b^{*}$ yellow). $\Delta \mathrm{E}^{*}$ values $\leq 3.3$ were considered clinically acceptable for color variation, not relevant and not perceptible ${ }^{13,20}$.

Roughness, lightness and color parameters were collected in five observation periods: $\mathrm{T} 0=$ baseline (one week after disk preparation); $\mathrm{T} 1=$ one week after the first bleaching treatment; $\mathrm{T} 2=$ one week after polishing, $\mathrm{T} 3=$ one week after the second bleaching treatment; T4 = two weeks after the second bleaching treatment. The parameter's variations were calculated between each observation period and baseline, and between every two consecutive observation periods.

The data were statistically analyzed using Statistica software (Version 10, StatSoft Inc., USA). Before the light variation analysis, the values were squared for handling the negative values.
A repeated measures analysis of variance (ANOVA) was used to analyze the significant differences between the variables with a significance level of 0.05 . Whenever there was a significant interaction between them, a post hoc Tukey's test was used to detect specific differences with a significance level of 0.05 .

\section{Results}

The mean values and standard deviations of color variation, lightness variation and roughness for the resin-modified glassionomer cement and the nanohybrid resin composite, after bleaching and polishing are summarized in Tables 2, 3 and 4. The analysis of variance (ANOVA) revealed a highly significant difference $(p=0.000)$ between the independent variables for Color and Lightness variation. These indicated that bleaching and polishing had a significant effect on the materials investigated.

Table 2 - Mean values (Standard deviation) of Color variation $\Delta \mathrm{E}^{*}$ and Lightness variation $\Delta \mathrm{L}^{*}$ of Vitremer and Z250 $\mathrm{XT}$, between each time period and baseline.

\begin{tabular}{ccccc}
\hline Material & $\Delta \mathrm{E}^{*} 1$ & $\Delta \mathrm{E}^{*} 2$ & $\Delta \mathrm{E}^{*} 3$ & $\Delta \mathrm{E}^{*} 4$ \\
Vitremer & $17.42( \pm 1.84)^{\mathrm{e}}$ & $16.14( \pm 1.83)^{\mathrm{b}}$ & $15.87( \pm 1.75)^{\mathrm{b}}$ & $14.41( \pm 1.86)^{\mathrm{d}}$ \\
Z250XT & $1.48( \pm 0.73)^{\mathrm{a}}$ & $1.70( \pm 0.74)^{\mathrm{a}}$ & $1.46( \pm 0.94)^{\mathrm{a}}$ & $2.37( \pm 0.49)^{\mathrm{c}}$ \\
& $\Delta \mathrm{L}^{*} 1$ & $\Delta \mathrm{L}^{*} 2$ & $\Delta \mathrm{L}^{*} 3$ & $\Delta \mathrm{L}^{*} 4$ \\
Vitremer & $41.11( \pm 17.57)^{\mathrm{d}}$ & $19.25( \pm 10.27)^{\mathrm{c}}$ & $13.31( \pm 8.20)^{\mathrm{b}, \mathrm{c}}$ & $8.29( \pm 4.80)^{\mathrm{a}, \mathrm{b}}$ \\
Z250XT & $1.07( \pm 1.27)^{\mathrm{a}}$ & $1.41( \pm 1.79)^{\mathrm{a}}$ & $1.57( \pm 2.44)^{\mathrm{a}}$ & $1.27( \pm 1.61)^{\mathrm{a}}$ \\
\hline
\end{tabular}

Values with the same superscript letters in each group were not statistically significant differences at $\mathrm{p} \geq 0.05, \mathrm{n}=12$.

Table 3 - Mean values (Standard deviation) of and Color variation $\Delta \mathrm{E}^{*}$ and Lightness variation $\Delta \mathrm{L}^{*}$ of Vitremer and Z250 XT between each time period: $\Delta 1$ (between T1 and T0), $\Delta 2$ (between T2 and T1), $\Delta 3$ (between T3 and T2), $\Delta 4$ (between T4 and T3).

\begin{tabular}{|c|c|c|c|c|}
\hline Material & $\Delta \mathrm{E}^{\star 1}$ & $\Delta \mathrm{E}^{\star 2} 2$ & $\Delta E^{\star} 3$ & $\Delta \mathrm{E}^{\star} 4$ \\
\hline Vitremer & $17.42( \pm 1.84)^{c}$ & $2.31( \pm 0.78)^{\mathrm{a}}$ & $1.38( \pm 0.91)^{b}$ & $2.13( \pm 0.85)^{\mathrm{a}}$ \\
\hline \multirow[t]{2}{*}{ Z250XT } & $1.48( \pm 0.73)^{a, b}$ & $0.51( \pm 0.14)^{b}$ & $0.73( \pm 0.49)^{a, b}$ & $2.03( \pm 0.63)^{a}$ \\
\hline & $\Delta \mathrm{L}^{* 1}$ & $\Delta \mathrm{L}^{*} 2$ & $\Delta L^{*} 3$ & $\Delta \mathrm{L}^{*} 4$ \\
\hline Vitremer & $41.11( \pm 17.57)^{b}$ & $5.13( \pm 3.48)^{\mathrm{a}}$ & $1.03( \pm 1.49)^{\mathrm{a}}$ & $2.26( \pm 2.21)^{\mathrm{a}}$ \\
\hline Z250XT & $1.07( \pm 1.27)^{\mathrm{a}}$ & $0.11( \pm 0.09)^{\mathrm{a}}$ & $0.39( \pm 0.97)^{\mathrm{a}}$ & $1.41( \pm 2.15)^{\mathrm{a}}$ \\
\hline
\end{tabular}

Values with the same superscript letters in each group were not statistically significant differences at $\mathrm{p} \geq 0.05, \mathrm{n}=12$.

Table 4 - Mean values (Standard deviation) of Roughness $(\mu \mathrm{m})$ of Vitremer and Z250 XT observed in the periods T0, T1, T2, T3, and T4

\begin{tabular}{cccccc}
\hline Material & Ra0 & Ra1 & Ra2 & Ra3 & Ra4 \\
\hline Vitremer & $0.31( \pm 0.17)^{\mathrm{a}, \mathrm{b}}$ & $0.27( \pm 0.15)^{\mathrm{a}, \mathrm{b}}$ & $0.48( \pm 0.20)^{\mathrm{c}, \mathrm{d}}$ & $0.66( \pm 0.31)^{\mathrm{d}}$ & $0.61( \pm 0.27)^{\mathrm{c}, \mathrm{d}}$ \\
Z250XT & $0.16( \pm 0.11)^{\mathrm{a}}$ & $0.24( \pm 0.22)^{\mathrm{a}, \mathrm{b}}$ & $0.36( \pm 0.36)^{\mathrm{a}, \mathrm{b}, \mathrm{c}}$ & $0.31( \pm 0.12)^{\mathrm{a}, \mathrm{b}}$ & $0.34( \pm 0.08)^{\mathrm{a}, \mathrm{b}, \mathrm{c}}$ \\
\hline
\end{tabular}

Values with the same superscript letters were not statistically significant differences at $p \geq 0.05, n=12$.

The analyses of color variation $\left(\Delta \mathrm{E}^{*}\right)$ and lightness variation $\left(\Delta \mathrm{L}^{*}\right)$ for Vitremer, between baseline and observation periods (Table 2), and between observation periods (Table 3) showed that alterations promoted by the bleaching procedure were significant after the first bleaching procedure (T1), on the material protected by the gloss. Significant color variation for Filtek Z250 XT was detected in the last observation period (T4) compared to baseline, after polishing, bleaching and storage of the material (Table 2). The analyses of lightness variation for Filtek Z250 XT showed that alterations promoted by bleaching and polishing, between baseline 
and observation periods (Table 2), and between observation periods (Table 3), were not significant.

The difference of roughness between the materials and observation periods was significant $(p<0.000)$. The analyses of the roughness values $(\mathrm{Ra})$ for Vitremer demonstrated that the superficial modification promoted by the polishing procedure was significant and increased roughness, comparing both initial periods with the three final ones (Table 4). However, the bleaching effect onto roughness was not significant (Table 4). The analyses of roughness for Filtek Z250 XT revealed that the superficial alteration promoted by the bleaching and polishing procedures was not significant, as well as the variation of roughness promoted by bleaching onto smooth surface and roughened surface (Table 4).

\section{Discussion}

The null hypothesis was rejected for Z250 XT, because the color alteration of the nanohybrid composite was significant, but in a clinically acceptable range of color change $\left(\Delta \mathrm{E}^{*} 4=2.37\right)$. The $\Delta \mathrm{E}^{*}$ value is considered clinically undetectable if less than 1 , acceptable if between 1 and 3.3 and unacceptable if greater than $3.3^{13,20}$. The roughness variation due to bleaching onto smooth surface and polished composite surface was not significant.

The color alteration observed on the resin-modified glassionomer, due to the first bleaching treatment with $35 \% \mathrm{HP}$, was significant and clinically detectable $\left(\Delta \mathrm{E}^{*} 1=17.42\right)$. It was not due to superficial color alteration of the specimens, but intrinsic color change, because it persisted with time, even after the wear promoted by the polishing procedure. The substantial and positive $\Delta \mathrm{L}^{*}$ for Vitremer, after the first bleaching treatment would de clinically unacceptable, if the natural dental structure did not lighten to the same degree. The color change in experimental subsequent periods was acceptable $\left(\Delta \mathrm{E}^{*} \leq 2.31\right)$, with a tendency for recuperation towards the original color and lightness, but without matching them. Vitremer roughness increased after polishing, but was not affected significantly after the bleaching agent was applied onto the more irregular surface.

The choice of these parameters should be elucidated, because roughness can promote greater accumulation of food debris, biofilm formation, and increased colonization by cariogenic bacteria ${ }^{21}$; and alteration of color may impair the aesthetics. Unacceptable color match of restorations, which may discolor more easily than teeth after prolonged exposure to the oral environment, is one reason for replacement of restorations. The present study analysed the color change of two restorative materials without any previous discoloration, both shade A3 as provided by the manufacturer. The in-office bleaching procedure used was recommended by the manufacturer, in order to represent the clinical conditions without continuous exposure or simulating the cumulative effect over a period of time.

The gloss applied onto the resin-modified glass-ionomer, immediately after restoration, protects the material from syneresis and imbibition. Surface protection is also recommended onto earlier restorations of glass-ionomer, when using rubber dam isolation and topical application of fluoride. The initial smooth surface with the gloss did not protect the material from intrinsic color change caused by the bleaching. The significant color alteration of the resin-modified glass-ionomer from the first bleaching treatment could be clinically detectable, and continued throughout of the experiments. The present study corroborates with a previous one, which compared the color stability of fluoridecontaining restorative materials and composites, and observed significant difference in color of ionomer cements ${ }^{22}$. The bleaching effect difference between the two shade A3 products might be due to water affinity, because the hydrophilic resin modified glassionomer cement showed lower intrinsic color stability than the hydrophobic nanohybrid composite ${ }^{22}$.

Some studies affirm that bleaching agents can remove the extrinsic staining from composite resins, but not promote intrinsic color change $\mathrm{e}^{13,23}$. The intrinsic color alteration of the nanohybrid composite tested in this study, two weeks after the second bleaching, was significant, but considered clinically undetectable (mean $\Delta \mathrm{E}^{*}$ value $<3.3$ ). One limitation of this study is that no control was used to verify the color or roughness change caused by the storage of the specimens, immersed in distilled water at $37^{\circ} \mathrm{C}$ during the study period of 9 weeks.

The superficial alteration promoted by the bleaching and polishing procedures onto Filtek Z250 XT was not significant. Studies with composites reported no observable or significant roughness alteration after bleaching ${ }^{9,24}$, and no significant effect on the microhardness ${ }^{14,24,25}$; agreeing that no replacement of restorations may be required after bleaching. It is recommended caution in bleaching treatments when restorations are present, in order to minimize the impact of bleaching therapies on restorative materials and restorations ${ }^{3,5}$. Bleaching treatments may affect the color and surface roughness of existing restorations, and even though the alterations may not be clinically relevant to indicate the replacement of the restoration, they require close monitoring by the dentist and should not be used indiscriminately when restorations are present.

Color matching may be a problem when the intrinsic restoration color matches the dental element before bleaching. In the case of a composite restoration, it will remain unchanged, contrasting with the altered dental color after bleaching. However, resin-modified glass ionomer restoration will present color alteration with the bleaching.

\section{Conclusions}

Within the limits of the present study, it can be concluded that the in-office bleaching material caused significant and clinically detectable alterations on color of a resin-modified glass-ionomer cement. Therefore, this study contraindicates the application of in-office bleaching products on resin-modified glass ionomer restorations, if the color shade is to be maintained, and also polishing after bleaching.

The 35\% HP bleaching material also caused significant alteration on the intrinsic color of a nanohybrid composite, but it is considered clinically undetectable. Therefore, this study does not contraindicate the application of bleaching gel on the composite, or polishing the restoration after bleaching.

Even though there is no sufficient reason to indicate the 
replacement of restorations after bleaching, this may be necessary to match the color variation of the dental elements.

\section{References}

1. Basting RT, Amaral FL, Franca FM, Florio FM. Clinical comparative study of the effectiveness of and tooth sensitivity to $10 \%$ and $20 \%$ carbamide peroxide home-use and $35 \%$ and $38 \%$ hydrogen peroxide in-office bleaching materials containing desensitizing agents. Oper Dent. 2012 Sep-Oct;37(5):464-73. doi: 10.2341/11-337-C.

2. Meireles SS, Fontes ST, Coimbra LA, Della Bona A, Demarco FF. Effectiveness of different carbamide peroxide concentrations used for tooth bleaching: an in vitro study. J Appl Oral Sci. 2012 MarApr;20(2):186-91.

3. Attin T, Hannig C, Wiegand A, Attin R. Effect of bleaching on restorative materials and restorations--a systematic review. Dent Mater. 2004 Nov;20(9):852-61.

4. Dutra RA, Branco JR, Alvim HH, Poletto LT, Albuquerque RC. Effect of hydrogen peroxide topical application on the enamel and composite resin surfaces and interface. Indian J Dent Res. 2009 Jan-Mar;20(1):65-70.

5. Yalcin F, Gurgan S. Effect of two different bleaching regimens on the gloss of tooth colored restorative materials. Dent Mater. 2005 May;21(5):464-8.

6. Gurgan S, Yalcin F. The effect of 2 different bleaching regimens on the surface roughness and hardness of tooth-colored restorative materials. Quintessence Int. 2007 Feb;38(2):e83-7.

7. Bittencourt BF, Gomes GM, Trentini FA, Azevedo MR, Gomes JC, Gomes MM. Effect of finishing and polishing on surface roughness of composite resins after bleaching. Braz J Oral Sci. 2014 Apr-Jun;13(2):158-162. doi: 10.1590/1677-3225v13n2a15.

8. Hannig C, Duong S, Becker K, Brunner E, Kahler E, Attin T. Effect of bleaching on subsurface micro-hardness of composite and a polyacid modified composite. Dent Mater. 2007 Feb;23(2):198-203.

9. Wang L, Francisconi LF, Atta MT, Dos Santos JR, Del Padre NC, Gonini $A \mathrm{Jr}$, et al. Effect of bleaching gels on surface roughness of nanofilled composite resins. Eur J Dent. 2011 Apr;5(2):173-9.

10. Londono J, Abreu A, Nelson S, Hernandez J, Torres C, Mettenburg $D$, et al. Effect of vital tooth bleaching on solubility and roughness of dental cements. J Prosthet Dent. 2009 Sep;102(3):148-54 doi: 10.1016/ S0022-3913(09)60136-0.

11. Turker SB, Biskin T. Effect of three bleaching agents on the surface properties of three different esthetic restorative materials. J Prosthet
Dent. 2003 May;89(5):466-73.

12. Bondarenko VI. [Growing D. sibiricus and murinus in cell cultures]. Zh Mikrobiol Epidemiol Immunobiol. 1967 Apr;44(4):135. Russian.

13. Villalta P, Lu H, Okte Z, Garcia-Godoy F, Powers JM. Effects of staining and bleaching on color change of dental composite resins. J Prosthet Dent. 2006 Feb;95(2):137-42.

14. Mourouzis P, Koulaouzidou EA, Helvatjoglu-Antoniades M. Effect of inoffice bleaching agents on physical properties of dental composite resins. Quintessence Int. 2013 Apr;44(4):295-302. doi: 10.3290/j.qi.a29154.

15. Irawan BA, Irawan SN, Masudi SM, Sukminingrum N, Alam MK. 3D Surface Profile and Color Stability of Tooth Colored Filling Materials after Bleaching. Biomed Res Int. 2015;2015:327289. doi: 10.1155/2015/327289.

16. Rosentritt M, Lang R, Plein T, Behr M, Handel G. Discoloration of restorative materials after bleaching application. Quintessence Int. 2005 Jan;36(1):33-9.

17. Durner J, Obermaier J, llie N. Investigation of different bleaching conditions on the amount of elutable substances from nano-hybrid composites. Dent Mater. 2014 Feb;30(2):192-9. doi: 10.1016/j. dental.2013.11.003.

18. Tabatabaee MH, Arami S, Ghavam M, Rezaii A. Monomer release from nanofilled and microhybrid dental composites after bleaching. J Dent (Tehran). 2014 Jan;11(1):56-66.

19. Johnston WM. Color measurement in dentistry. J Dent. 2009;37 Suppl 1:e2-6. doi: 10.1016/j.jdent.2009.03.011.

20. Canay S, Cehreli MC. The effect of current bleaching agents on the color of light-polymerized composites in vitro. J Prosthet Dent. 2003 May;89(5):474-8.

21. Mor C, Steinberg D, Dogan H, Rotstein I. Bacterial adherence to bleached surfaces of composite resin in vitro. Oral Surg Oral Med Oral Pathol Oral Radiol Endod. 1998 Nov;86(5):582-6.

22. lazzetti G, Burgess JO, Gardiner D, Ripps A. Color stability of fluoridecontaining restorative materials. Oper Dent. 2000 Nov-Dec;25(6):520-5.

23. Silva Costa SX, Becker AB, de Souza Rastelli AN, de Castro Monteiro Loffredo L, de Andrade MF, Bagnato VS. Effect of four bleaching regimens on color changes and microhardness of dental nanofilled composite. Int J Dent. 2009;2009:313845. doi: 10.1155/2009/313845.

24. Sharafeddin F, Jamalipour $\mathrm{G}$. Effects of $35 \%$ carbamide peroxide gel on surface roughness and hardness of composite resins. J Dent (Tehran). 2010 Winter;7(1):6-12

25. Polydorou O, Hammad M, Konig A, Hellwig E, Kummerer K. Release of monomers from different core build-up materials. Dent Mater. 2009 Sep;25(9):1090-5. doi: 10.1016/j.dental.2009.02.014. 